\title{
Impaired translations: IFRS from English and annual reports into English
}

Christopher Nobes, Royal Holloway (University of London) and University of Sydney

\author{
Christian Stadler, Lancaster University
}

\section{Acknowledgements}

The authors are grateful for comments on previous drafts from Holger Daske, Lisa Evans, Elena Giovannoni, Erlend Kvaal, Jérémy Morales, Stephen Zeff and workshop participants at the 2018 British Accounting and Finance Association Annual Conference and the 2018 European Accounting Association Annual Congress. They are also grateful for suggestions from two reviewers of this journal and from the editor who handled our paper, Rania Kamla. They acknowledge translation and other assistance from Abdullah Almulhim, Mohammed Alomair, Aysha AlSalih, Jörgen Dahlgren, Jürgen Ernstberger, Isabel Lourenço, Sven-Arne Nilsson, Takatsugu Ochi, Sang-Eun Park, Jon Rowden, Chungwoo Suh, Satenik Vanyan, Piotr Zegarlinski, Geert Wognum and $\mathrm{Na}$ Zhao. The support of the ICAEW's charitable trusts is gratefully acknowledged. 


\title{
Impaired translations: IFRS from English and annual reports into English
}

\begin{abstract}
Purpose - The authors examine translation in the context of IFRS by taking the example of the English term "impairment" in IAS 36, and following it into 19 translations. They then examine the terms used for impairment in English translations of annual reports provided by firms. Consideration is given to the best approach for translating regulations and whether that is also suitable for the translation of annual reports.
\end{abstract}

Design/methodology/approach - The two empirical parts of the paper involve: (i) identifying the terms for impairment used in 19 official translations of IAS 36, and (ii) examining English-language translations of reports provided by 393 listed firms from 11 major countries.

Findings - Nearly all the terms used for 'impairment' in translations of IAS 36 do not convey the message of damage to assets. In annual reports translated into English, many terms are misleading in that they do not mention impairment, peaking at 39\% in German and Italian reports in one year.

Research implications - Researchers should note that the information related to impairment in international databases is likely to contain errors, and we recommend that data should be hand-collected and then carefully checked by experts. We make suggestions for further research.

Practical implications - Translators of regulations should aim to convey the messages of the source documents, but translators of annual reports should not look only at the reports but also consult the terminology in the original regulations. The authors also suggest implications for regulators and analysts.

Originality/value - The paper innovates by separately considering regulations and annual reports. The authors examine a key accounting term systematically into a wide range of official translations. The core section of the paper is a new field of research: an empirical study of the translations of firms' financial statements.

Keywords Translation, IFRS, Impairment, International differences

Paper type Research paper 


\section{Introduction}

The difficulties of translating accounting terms have been examined by researchers over many decades (e.g., Rutherford, 1983; Walton, 1991; Parker, 1994; Evans, 2004; Dahlgren and Nilsson, 2012; Evans et al., 2015; Kettunen, 2017). Nobes (2006) includes translation problems as one of the eight causes of international differences in practice under International Financial Reporting Standards (IFRS). Zeff (2007) includes translation and terminology in his survey of obstacles to global comparability of financial reporting. The IFRS Foundation (2016) acknowledges the importance of good translations in enhancing international comparability. Cooper and Robson (2006, p. 436) call for more research on the dispersed sites of accounting regulation, and translation is one of these.

Most research on translation in the context of accounting has two factors in common: it deals with translation from English to other European languages and it concerns official documents, mostly relating to either "a true and fair view" (TFV) or, in more recent research, IFRS. Our first contribution is to add to the literature on the translation of IFRS by revealing particular problems associated with a topic which has received little attention: "impairment", in the context of IAS 36 (Impairment of Assets). We first examine 19 translations of "impairment" in official documents, concluding that few of them preserve the message in the original. We draw policy implications for the International Accounting Standards Board (IASB) as it writes standards and for the translators of those standards. 
After that, our main contribution is to open up a new aspect of accounting research: empirical investigation of a large sample of translations of annual reports. By doing so, we respond to a specific call by Kettunen (2017, p. 53) for research into the preparation of translated annual reports. We continue to focus on impairment, in a way which enables a holistic view of the terms used for this important concept: from their origins in the USA, to IFRS as issued in English, through to translations of the accounting standard and then back into English in translated annual reports. We find translations of IAS 36's "impairment" which are too broad, and this feeds through to non-English annual reports. This in turn causes translators of those reports (into target English) to produce misleading translations such as provision, allowance, write-down and depreciation. We provide evidence suggesting that analysts and researchers who use Worldscope data are then likely to be misled by these terms. An implication for translators of annual reports (as opposed to translators of regulations) is that they should not just look at the documents they are translating but should consider the original source IFRS standards.

We hope that readers will excuse any apparent bias towards English. This journal is written in English, so it is convenient to discuss problems with technical terms (some of which already exist before any translation of them) by using English terms. Also, IFRS is written in English, so our study of a particular standard begins there. Furthermore, the great bulk of translated annual reports in the world have been translated into English rather than into any other language, so this sets the scope for our empirical study. Many of the examples and conclusions would probably apply, mutatis mutandis, if the journal or the standards or the translated reports used another language. Only one of the authors has English as mother tongue. 
The paper proceeds as follows. In Section 2, we briefly examine theories relating to words and to the translation of them, with particular reference to accounting documents. Section 3 examines the major problems related to translating IAS 36's term “impairment”. Section 4 deals with prior literature on translated annual reports and with the setting up of our empirical study of the terms used for impairment in the English translations of a large sample of annual reports of listed firms. Section 5 sets out the findings of our study. Section 6 presents conclusions and policy recommendations for the IASB, for translators of IFRS and of annual reports, and for analysts and researchers.

\section{Some theory}

\subsection{Signifiers}

This sub-section briefly summarises some literature about the theory of words, before any issues of translation are considered. Saussure (1910) distinguishes between a signifier (the "signifying element", i.e. the word or sound, e.g., "asset") and what is being signified (the "signified element", i.e. the meaning of the concept, e.g., in the context of accounting, an asset is a resource controlled by an entity). ${ }^{1}$ These ideas were applied to accounting by Walton (1991) and Parker (1994). Archer and McLeay (1991) and then Evans, Baskerville and Nara (2015) discuss the fact that signifiers are used in different "registers", 2 particularly an everyday register and a technical register such as an

1 Roy Harris, one of the translators of Saussure, suggests that "signifying element" and "signified element" are better translations of Saussure's French "signifiant" and "signifié" (see Saussure, 1910, p. xix).

2 A register can be related to the concept of a 'language for specific purposes' (LSP). Some writers use 'LSP' to mean a variety of language used by members of a specific subject field. 
accounting register. For example, "asset" has a much wider meaning in the everyday register than in the accounting register.

There is no essential reason why a particular signifier should be attached to a particular signified. Saussure (1910, p. 76) concluded that the "linguistic sign is arbitrary". In principle, any signifier can be used as long as there is agreement and consistency within a register. For example, at first sight, any signifier could be used in the accounting register for what now has the signifier "impairment". One approach, often used in sciences, is for the technical register to coin new terms, ${ }^{3}$ perhaps using Latin or Greek words. However, problems can arise if a technical register uses a term from the everyday register but defines it differently. In an "almost iconic"4 legal opinion on TFV, Arden (1993, para. 14) considers a case where the technical register does not define terms:

... the Court will not in my view seek to find synonyms for the words 'true' and 'fair' but will seek to apply the concepts which those words imply.

We might interpret Arden as saying that, in the context of English law, the Court would infer the meaning in the everyday register, given that the words were not defined in law.

A particular example of a perilous difference in registers is where a hypernym (a word with a broad meaning $)^{5}$ from the everyday register is adopted as a narrow signifier

Others use LSP with the more technical meaning of an applied approach to teaching a foreign language in a particular field (e.g. Fuertes-Olivera and Nielsen, 2011).

3 From here on, we generally use 'term' instead of 'signifier'.

4 Moore (2008, para. 7) uses this description in a later legal opinion.

5 A hypernym signifies a category to which words with more specific meanings are subordinate. For example, 'colour' is a hypernym which includes 'green'. 
in the technical register. In accounting, there is an additional difficulty when it comes to documents written by practitioners (as opposed to standards written for practitioners): whereas medical reports (for example) are not primarily aimed at non-medics, financial reports are primarily addressed to non-accountants who might not appreciate that they are reading technical terms.

\subsection{Translation theory and its application to accounting documents}

The problems relating to technical registers were discussed above in the context of a monoglot world, particularly one using English. The problems can worsen in the context of translation. For example, the use of a hypernym in a regulation may lead to new difficulties when translated. Huerta, Petrides and Braun (2013) investigate translation of accounting terms by senior Spanish-speaking accounting students. They divide their terms into generic (such as "probable") and accounting-specific (such as "asset") which have definitions in specialised dictionaries. They find that, when the terms are translated, the generic terms display the greater variability of interpretation (p. 10). This problem can occur even when the translator is a technical expert but is more likely for the non-experts often responsible for translating IFRS (see later in this section). Furthermore, the annual reports which result from applying the regulations are often translated by non-accountants and then read by other non-accountants. 
Translators begin with a "source text" process involves the generation of options and then selection from among them. There are competing paradigms in translation theory, particularly equivalence and skopos theory. The first suggests that translators should aim to produce a target text of equal value to the source text, and the second focuses on the purpose of the translation. We now investigate these paradigms in the context of translating accounting documents.

Underlying equivalence is the idea that there must be a message that stands outside of both the source and target languages to which the translator can refer: a tertium comparationis. A modern application of this idea is localisation theory (Dunne, 2006). For example, Microsoft originally dealt in only a few foreign markets, so translated its menus, date formats etc. from American English to French, English to German, and so on. Now that far more language versions are necessary, an artificial internationalised English version is created, attempting to remove cultural references, and this is the source text for the translations.

However, there are philosophical difficulties with the idea of a tertium comparationis. There is a measure of indeterminacy in translation (Quine, 1969), and one can never be sure whether transmission of meaning has been achieved. Translators inevitably depart from the source text and cannot represent it fully (Chau, 1984). In the context of accounting, Dahlgren and Nilsson (2012) consider that, because conceptual structures in different languages do not match perfectly, some concepts are "simply not

6 Some writers prefer "start text" (e.g. Pym, 2014, p. 2) because the start text itself might be a translation. In the context of this paper the start texts, such as accounting standards, are clearly also source texts. 
translatable" (p. 57). This was a conclusion reached earlier about the "true and fair view" by Alexander (1993, p. 283).

However, Baskerville and Evans (2011, p. 29), after analysing the responses to a survey of 67 experts involved in translation of accounting documents or textbooks from English into various European languages, conclude more hopefully that translation is possible, although direct equivalence cannot generally be achieved. Thus, although we note Heidegger's (1957, p. 163) conclusion that poems cannot successfully be translated, we focus instead on his contrasting view that business letters can be; a contrast endorsed, for the translation of accounting texts, by a respondent of Baskerville and Evans (2011, p. 29).

An illustration of the difficulty of translation concerns terms for colours; for example, the French word 'vert' is not fully equivalent to the English word 'green'? However, suppose that the French government wanted to produce an English translation of its traffic code, to give to British motorists arriving in Calais. On the subject of traffic lights, translator X might suggest: 'Drivers may proceed when the light is green'. However, a more fastidious translator, $\mathrm{Y}$, who is aware of the serious equivalence problems might propose: 'Drivers may proceed when the light is coloured'. Although 'green' is not exactly equivalent to 'vert', we suggest that it is suitable because it conveys the meaning well enough, and it is more proximate than the hypernym. From here on, we will not generally refer to equivalence, but to 'proximate' translations, by which we mean those which are likely to minimise ambiguity and to be successful in getting the source

7 Evans (2004, pp. 240-241) discusses the translation of terms for colours. 
message across. However, when referring to prior literature, we will sometimes retain the use of 'equivalent'.

In the context of concerns about equivalence, skopos theory was developed. It holds that translators should serve the purpose of the translation (e.g. Schäffner, 2001; Vermeer, 2012). This means that the translators must investigate the reasons for the translation. Translation thus involves "dethroning" the source text. This might be an appropriate paradigm in some fields (perhaps advertising or propaganda) but, in our view, it is not helpful in the context of accounting regulations (as opposed to annual reports). We now illustrate this with the example of translation of the EU's Fourth Directive on company law.

The Directive was created in French and first published in draft in 1971, before Denmark, Ireland and the UK joined the EU in $1973 .{ }^{8}$ After this expansion, there was a published re-draft in 1974 which included the concept of "a true and fair view" (TFV), specifically borrowed from the English language and the UK legal context. Especially as TFV is an overriding concept, this led to great discussion about its meaning in continental Europe (Alexander, 1993). Sometimes, part of the problem of translation is that the meaning is not clear even in the original, and this was abundantly the case with TFV (e.g. Rutherford, 1985). Researchers later examined translations into many languages (e.g. Nobes, 1993; Zeff, Buijink and Camfferman, 1999; Aisbitt and Nobes, 2001; KosmalaMacLullich, 2003), noting that most translations were far from literal. Translations of TFV included: (i) une image fidèle (the French translation using one adjective instead of

8 See, for example, Nobes (1993). 
the two in English), (ii) la imagen fiel (the Spanish law ${ }^{9}$ using the definite rather than the indefinite article), (iii) rappresentare in modo veritiero e corretto (the Italian law ${ }^{10}$ using two adjectives but not necessarily ones closely proximate to the English), and (iv) unter Beachtung der Grundsätze ordnungsmässiger Buchführung ein den tatsächlichen Verhältnissen entsprechendes Bild (the German law's elaboration of "true"). ${ }^{11}$

The German, Spanish and Italian signifiers for TFV were used in national laws to supplant those provided by the EU in the national language versions of the Directive which it sent to member states. ${ }^{12}$ The German elaboration of "true" neuters even that concept by inventing the overriding need to comply with established norms. This involved two departures from the original German version of the Directive, ${ }^{13}$ and these were intentional in order to avoid changes to German accounting, particularly the uncertainty that would have been introduced by recourse to a vague new principle (Ordelheide, 1990, p. 13). In terms of skopos theory, the result was a good translation because it fitted the purpose of the German government, but we suggest that it does not convey the same message as in the source, and this undermines the purpose of the document (as opposed to the purpose of the translation) which was to achieve international harmonisation. Similarly, the Spanish government's translation of TFV (as

9 This is unlike the EU's translation of the Directive which had 'una imagen fiel'.

10 This is unlike the EU's translation of the Directive which had one adjective 'fedele'.

11 This might be translated as "in compliance with accepted accounting principles, a picture in accordance with the facts".

12 Nobes (1993, Table 2) examines this. For example, the EU's Spanish translation contained the indefinite article.

13 The 1974 published draft of the Directive contained the apparently equivalent "einen getreuen Einblick" instead of the lengthy wording of German law quoted above. The second half of the new wording is in the Directive (perhaps by negotiation with the German government); the first phrase was added in Germany. 
opposed to the EU's translation) ${ }^{14}$ uses the definite article in order to reduce the apparent vagueness of the concept. This might have suited the purpose of the Spanish government (e.g., in its capacity as tax collector, to increase the certainty of accounting numbers) but the translation again departs from the originally intended message. The German and Spanish translations seem to be examples of deliberately attempting to change the meaning.

Kettunen (2017) examines the institutions involved in translating IFRS, using Finnish as an example. Kettunen (p. 43) contrasts the work of the EU's Directorate General for Translation (DGT) with that of a Translation Review Committee (TRC) of the IFRS Foundation, noting that only the latter involves accounting experts. ${ }^{15}$ Also, the DGT does not set out a specific objective for translation, whereas the IFRS Foundation states that translators should "render the English text into another language" but should neither "interpret or explain" nor "add, reduce or alter the substance and content of IFRSs" (IFRS Foundation, 2013, para. 3.3).

Two of Kettunen's (2017, pp. 47 and 48) examples of translation into Finnish are particularly interesting because the Finnish TRC decided not to act on the IASB's deliberate changes in terminology: (i) from 'valuation' of assets to 'measurement', and (ii) from 'balance sheet' to 'statement of financial position'. These changes can be seen as part of a major philosophical shift towards the use of fair value (Power, 2010), as

${ }^{14}$ See footnote 9 .

${ }^{15}$ Some EU translations (such as the Finnish and the German) are also approved by the IFRS Foundation, whereas other EU translations (such as the Italian and the Swedish) are not (see IFRS Foundation, 2017, section on 'Available translations'). 
follows: (i) the abandonment of the signifier 'valuation' points out that the conventional measurement basis for many assets (depreciated cost) has no economic meaning, and (ii) the abandonment of 'balance sheet' points out that the IASB would like to move towards a statement which is something better than merely a sheet of the year-end balances which remain in the double-entry system. ${ }^{16}$ Kettunen does not criticise the translations of the TRC, but suggests that its lack of reaction helped to 'maintain the equivalence of terminology' and to avoid differences in terminology between Finnish IFRS and Finnish law (p. 47). We take a different view. The lack of Finnish reaction suggests that the translators had a skopos (a long-running preference for particular terms ${ }^{17}$ and consistency with Finnish law) which was not consistent with the IFRS Foundation's remit.

From the arguments in the above paragraphs, we conclude that skopos theory is not a useful prescriptive paradigm for the translation of international regulations. This is because skopos and the aim of a proximate translation lead to the same result when international regulators are in charge of translation and specify its purpose as producing 'equivalent' regulations which will lead to internationally comparable financial statements. ${ }^{18}$ However, if other parties control translation, skopos might lead to deliberate changes in meaning, which would undermine the purpose of the regulations. Either way,

${ }^{16}$ IAS 1, para. BC 16.

17 We are grateful to Sven-Arne Nilsson for suggesting that, in Sweden and Finland, there are reasons related to accounting theory for preferring 'värdering' (valuation) (letter to the authors of 25.8.2017).

18 This can be inferred from Article 73 of the Treaty of Rome and the Regulation 1606/2002 (Preamble paragraphs 1, 2, 5, 7 and 11). It can also be seen in paragraph 6 of the IASB's Preface to International Financial Reporting Standards, as revised in 2010. 
we suggest a target of proximate translation, which is consistent with the guidance given to official translators of IFRS.

The aim of proximate translation does not imply the consistent use of literal translation. For example, Kosmala-MacLullich (2003) and Kosmala (2005) explain that there are many different words for "true" and "fair" in Polish. The interpretation in different countries depends on such issues as the nature of the legal system and the content of previous laws. Evans et al. (2015, p. 22) note that translators of biblical and legal texts had attempted literal translation but they suggest that this is unlikely to work well for principles-based standards. Archer and McLeay (1991) outline four techniques of non-literal translation: circumlocution, coinage, approximation and inter-language borrowing. These are augmented by Baskerville and Evans (2011, pp. 44-48). Dahlgren and Nilsson (2012) illustrate the four techniques with IFRS accounting examples.

Evans et al. (2015) examine the problems of translation in several disciplines, such as law, medicine, engineering and advertising. They conclude (p. 10) that a translator needs to distinguish the meaning of a term in a specialist register from its meaning in the everyday register. However, in law for example, it is not just everyday dictionaries that are dangerous but even technical dictionaries. Instead, the lack of exact equivalents leads to the need for "conceptual dictionaries" which explain the meaning of words in context. Evans (2004, p. 239) discusses the concept of the "misleading label" as an obstacle to good accounting harmonisation. One of the causes of this is a translator's use of a term which already exists in the target language with a different meaning from that now intended. Evans et al. (2015, p. 21) also warn against faux amis, such as the French 
"matériel" or the Swedish "materiell" which are too physical to convey the "material" of the English accounting register (Baskerville and Evans, 2011, p. 45).

Nobes and Parker (2010, p. 159) and Dahlgren and Nilsson (2012) give examples of straight-forward errors in official translations of IFRS. Back-translation is tried with several accounting examples by Dahlgren and Nilsson (2012, pp. 49-51) from English to Swedish and back. In their examples, back-translation fails, and there is lack of 'equivalence', which is sometimes caused by poor translation and sometimes because the target language has no appropriate term. However, we do not intend to rely on backtranslation as a test of the proximity of translations. For example, longer phrases might be able to convey the same meaning. In other fields, such as marketing, it has also been suggested one should not rely upon back-translation alone (Douglas and Craig, 2007).

\section{The origins and translation of the term "impairment"}

\subsection{Impairment in the English-speaking world}

As explained above, this paper focuses on impairment. This sub-section therefore provides brief reviews of the meaning of the term in everyday English and the development of impairment accounting standards in the English-speaking world. The everyday meaning is relevant because, unless a term is defined in the accounting register, it is likely to convey its everyday meaning to accountants (cf. the Arden "opinion" in Section 2.1). More importantly, as noted earlier, most readers of accounting reports are not accountants. 
The root of the word "impair" as an English verb is the Latin "impeiorare" (to make worse). However, there is also a rare adjective, "impair", which has another Latin root ("imparitas") and which means the opposite of "par", "pair" or "peer" (i.e. it means something unmatched or unequal). This latter meaning can also be found in "imparity". The related adjective in French is "impair" (unequal, uneven or odd, as in numbers). German accounting contains a formal concept of imparity (Imparitätsprinzip) which requires recognition of unrealised losses but not unrealised gains (Ballwieser, 2001, p. 1247). This is consistent with an unequal approach to asset write-downs in that they did not have to be reversed when circumstances improved. ${ }^{19}$

In the everyday English register, the word "impaired" is generally associated with reduced functionality of a faculty such as sight or hearing. The dictionaries define the verb as: "to spoil something or make it weaker so that it is less effective". ${ }^{20}$ Impairment is either the state of being impaired or the process of becoming impaired. There is the implication of damage to, or deterioration of, the faculty, which might have occurred before or during birth but might also happen later as a result of accident or disease. Sight or hearing would not be expected to become impaired because of use, but might atrophy as part of ageing. However, because dictionaries define verbs (rather than participles) they give the misleading impression, in this case, that impairment is a deliberate process.

19 This was partially dismantled by the Bilanzrechtsmodernisierungsgesetz (Accounting Law Modernization Act) of 2009 (Hoffmann and Detzen, 2013, p. 379).

20 This definition is from the Cambridge English Dictionary; see http://dictionary.cambridge.org/dictionary/english/impair; accessed 11.10.2016. The Oxford English Dictionary has this meaning, and also "To make worse, less valuable, or weaker". Chambers Dictionary has: "to damage or weaken something, especially in terms of its quality or strength". 
The accounting register in English is broadly in line with the dictionaries. That is, "impairment" is used to distinguish a particular cause of an asset write-down: physical or economic damage. With this sense, the term was mentioned in documents of the Financial Accounting Standards Board (FASB) in $1980 .{ }^{21}$ Then, in 1982, it appeared in both US and international standards: SFAS 61 (Accounting for Title Plant, para. 6) and IAS 16 (Property, Plant and Equipment, originally in para. 41). The term appeared again several times in US authoritative literature in the first half of the 1990s, this time in the titles of standards. ${ }^{22}$ Earlier related terms, which referred to the accounting result of impairment, had included "reduction in unamortized cost" (in APB Opinion 17), "estimated loss" (in APB Opinion 30) and "valuation allowance" (in SFAS 109). The term was then adopted in the UK standard and the international standard on impairment (FRS 11 and IAS 36) whereas the nearest related term in UK law (deriving from the Fourth Directive) is "permanent diminution in value" (e.g., Companies Act 1985, Sch. 4, para. 19(2)). We refer to these words as being part of the accounting register rather than the legal register because accounting standards and law are now ${ }^{23}$ so bound together that a distinction would not be useful. This is, a fortiori, the case in code law jurisdictions such as Germany. To take the example of the contents of IFRS in the UK or Germany, they are now inserted into EU Regulation 1606/2002. ${ }^{24}$

${ }^{21}$ SFAS 121 (Appendix A, para.s 39-41) reports documents of 1980: one sent to the FASB by the American Institute of Certified Public Accountants, and one discussed by the FASB's Financial Accounting Advisory Council.

22 SFAS 114 (Accounting by Creditors for Impairment of a Loan) of May 1993, and SFAS 121 of March 1995.

${ }^{23}$ In the UK, at least since the Companies Act 1981.

${ }^{24}$ This paper is written in late 2017, before any changes to UK law resulting from leaving the EU. 
IAS 36 was issued in 1998. It requires an entity to be alert to any "indication" of impairment of an asset (such as physical damage; see para. 12) and, when observing one, to calculate the asset's "recoverable amount". If the latter is lower than the asset's carrying value, the asset must be written down to recoverable amount, with the related loss charged as an expense. IAS 36 differs in some respects from the slightly older US standard on impairment. ${ }^{25}$

As preparation for examining the translations of "impairment", we need to distinguish between four aspects of it: (a) an event (most obviously a physical one) involving economic damage to an asset, (b) the particular type of fall in value of an asset which is related to such an event; and then two aspects of the accounting recognition of some of those economic events, that is (c) the reduction in carrying value of the asset to recoverable amount (the credit) and (d) the impairment loss (the debit). IAS 36 is not clear about the distinction between (a) and (b). Remarkably, the standard does not define impairment, but seems to imply (in para. 8) that it only happens when (b) occurs to such an extent that recoverable amount is below carrying amount. This lack of clarity in the source language may have contributed to the translation problems discussed below. Nevertheless, some matters are clear. First, some falls in value are not impairments; for example, falls in the value of non-current assets that are temporary or caused by the passing of time or by wear that had been expected. Second, some damage is not recognised as impairment; for example, where damage to a single machine is covered up

25 SFAS 121 (Accounting for the Impairment of Long-lived Assets and for Long-lived Assets to be Disposed of) was issued in 1995 and is now part of the Accounting Standards Codification 3610-35. It does not allow reversals of impairment whereas IAS 36 (para. 10) requires them where appropriate. 
because impairment testing operates on a larger cash generating unit or where damage is not severe enough to reduce recoverable amount below carrying amount.

A further preparation for our discussions below is a note on the meaning, in the English accounting register, of "depreciation". To take the example of IAS 16, depreciation is defined as "the systematic allocation of the depreciable amount of an asset over its useful life" (para. 6). Similar definitions can be found in prior UK and US standards. Therefore, impairment is not a form of depreciation because it is an unsystematic reaction to an unplanned event. This clear distinction between depreciation and impairment is the relatively recent result of detailed accounting standards. Zucca and Campbell (1992, p. 35) show that $15 \%$ of their sample US firms in the early 1980s included "writedowns" in depreciation expense.

\subsection{Translations of "impairment"}

This sub-section's main task is to examine translations of IAS 36's term "impairment". However, before that, it will be helpful to look at the pre-IAS 36 term used in one particular language. In the German accounting register, the term "Abschreibung" (literally, off-writing) had been used to cover both depreciation and impairment. This led to such confusing policy explanations as the following from the English version of the 
last published consolidated annual report of Daimler under German GAAP, which was for the year 1995: $:^{26}$

Property, plant and equipment is valued at acquisition or manufacturing cost less accelerated depreciation. Additional depreciation is recorded where a lower reported amount is required.

An examination of the original German annual report shows that the "accelerated depreciation" in the first sentence is a translation of "planmäßige Abschreibungen" (literally, scheduled off-writings). Although the report's "accelerated depreciation" is a non-literal translation, the "depreciation" successfully conveys the two German words and the "accelerated" conveys useful extra information. Daimler's second sentence is about impairment; the lower required amount being that of the asset rather than the expense. The "additional depreciation" is a translation of "außerplanmäßige Abschreibungen" (literally, unscheduled off-writings). The German term is usefully descriptive but Daimler's translation of it does not convey the right message because, in the English accounting register, impairment is not a type of depreciation. We refer to "off-writing" as a translation because "writing off" has in practice the meaning of abandonment, as will be explained. We eschew “de-scribing” because that signifies something else. German law requires such unscheduled off-writing for property, plant

26 The English language report as published by Daimler-Benz AG for 1995, p. 54. From 1996 to 2006, Daimler provided US GAAP consolidated statements, after which it provided IFRS statements. 
and equipment in the case of a "voraussichtlich dauernden Wertminderung" (anticipatedly permanent value-lessening/reduction in value). ${ }^{27}$

We now examine IAS 36's term "impairment" in 19 translations: 12 European (including Russian), Argentinian Spanish, Brazilian Portuguese, Canadian French, Chinese, Japanese, Korean and Arabic. As will be explained, we find that nearly all the translations convey something much vaguer than (a) of sub-section 3.1 and nearly all convey something wider than either (a) or (b).

The German term for impairment in the IASB-approved translation of IAS 36 and in the official EU translation of it is "Wertminderung". It would surely have been clearer to use a term relating to damage. There is evidence that some German firms are aware of the lack of clarity because, even in their source German language reports, they use the English term as explanatory, referring for example to "Wertminderung (Impairment)". ${ }^{28}$

Looking further at Germanic languages, and concentrating on the title of IAS 36, we find that the Danish and Norwegian translations also literally refer to loss of value (vaerdiforringelse and verdifall, respectively). However, the Dutch were alert to the vagueness of this and used "bijzondere waardevermindering" (exceptional fall in value), as a new term in the accounting register. ${ }^{29}$ Dahlgren and Nilsson $(2012$, p. 51$)$ include impairment in their examination of the problems of translating IFRS into Swedish. They

${ }^{27}$ Handelsgesetzbuch, § 253(2) before and § 253(3) after the Bilanzrechtsmodernisierungsgesetz of 2009. In the equivalent UK law, the term for "Wertminderung" is "diminution in value" (Companies Act 2006, Regulations 2008, Schedule 1, para. 19 (2)).

28 See Continental 2013 and Henkel 2013.

29 Other terms, such as "buitengewoon" (extraordinary) were used in earlier law based on Article 35 of the Fourth Directive. We are grateful for assistance from Geert Wognum of PwC. 
note that "nedskrivningar" (literally "write-downs") is used in the title and in the text of IAS 36. We add the observation that the Swedish translation of the whole title "Impairment of Assets" is that one plural word for write-downs, suggesting a cavalier approach to translation on the part of the EU translators. We observe, further, that the Swedish term contrasts with the German, Danish, Norwegian and Dutch terms, which refer to a fall in value rather than to an accounting action. Dahlgren and Nilsson (2012, p. 51) note that the Swedish law already contained a loss-of-value term (värdenedgång) used to translate the Fourth Directive's instructions on permanent diminution in value. Dahlgren and Nilsson have suggested to the authors that the Swedish version of IAS 36 avoids rather than translates "impairment". ${ }^{30}$

Somewhat similarly, the full title of the standard in Arabic is الأصول قيمة إنخفاض, meaning approximately "reducing the recorded value of assets". A different Arabic word would denote impairment in the sense of weakening. ${ }^{31}$

Appendix 1 lists the terms for "impairment" used in all these translations of impairment (and further translations discussed below). The Appendix also records the exact documents to which we refer. Table 1 groups the translations according to approximate literal English meanings of the terms.

Turning to Romance languages, the terms in French (both EU and Canadian), Italian and Spanish (both EU and Argentinian) all refer to loss of value, which perhaps

${ }^{30}$ Letter from Jörgen Dahlgren to the authors of 29.8.2016.

31 The translation into English results from correspondence with Abdullah Almulhim of King Faisal University (13.9.2016), Aysha AlSalih of Princess Noura Bint Abdulrahmin University (14.9.2016), and Mohammed Alomair of Royal Holloway (19.7.2016). 
implies a real fall in value rather than an accounting action. These terms are, respectively: "dépréciation", "riduzione di valore" and "deterioro del valor". Fuertes-Olivera and Nielsen (2011, p. 163) report that Spanish texts had previously used "depreciación", and suggest that "deterioro" is potentially misleading.

A further linguistic twist is illustrated by the term for impairment in the Portuguese official EU translation: "imparidade". Nobes (1993) noted that the Portuguese have paid particular attention to English source accounting terms, being unusual in translating "true and fair" with two adjectives (verdadeira e apropriada), rather than using a single one such as "fidèle" or "fiel" in French and Spanish, respectively. For IAS 36, the translators into Portuguese again eschewed the other Romance terms relating to loss of value, and apparently looked directly to English. However, their choice of "imparidade" meant (in the everyday Portuguese register) inequality/imparity, ${ }^{32}$ which suggests that the EU translators were caught out by the superabundance of English words and did not realise that "imparity" means something quite different from "impairment", as discussed in subsection 3.1. Isabel Lourenço reports that Portuguese accountants were bemused by "imparidade" when they first saw it in IAS $36 .{ }^{33}$

The IFRS Foundation's Brazilian Portuguese translation does not make the same mistake as the EU Portuguese because it uses a different phrase for impairment: "redução ao valor recuperável" (reduction in recoverable value). This is a more informative

32 According to the Michaelis Dictionary, the word means 1. imparity; 2. inequality, disproportion; 3. quantitative or numerical unevenness (http://michaelis.uol.com.br/busca? $\mathrm{r}=1 \& \mathrm{f}=0 \& \mathrm{t}=1$ \&palavra=imparidade; accessed on 11.10.2016).

${ }^{33}$ Letter to the authors of 14.7.2016. 
translation than any of those above because it refers to the economic measure which leads to the recognised accounting result of the impairment, but it still does not refer to its cause of damage.

Like the main Romance languages, the two most-spoken Slavic languages have terms referring to loss of value: "utrata wartości" in Polish ${ }^{34}$ and "обесиенение" in Russian. ${ }^{35}$ The same applies in Finnish (a Finno-Ugric language), which has "arvon alentuminen".

The three major Asian languages (in terms of the importance of stock markets) are Chinese, Japanese and Korean. In each, there is a different interesting aspect to the translation of “impairment". In the Chinese translation of IAS 36, the characters are 减值 (pinyin: jiănzhí), meaning approximately “decrease in value”. However, where the standard discusses “impairment loss” (para. 6), its characters are 减值损失 (pinyin: jiănzhí sŭnshī), the third character of which (损) suggests “damage". ${ }^{36}$ In Japanese, a coinage was used for "impairment" by combining the characters for decreasing and losing (減損). Unlike in the Chinese, “damage” cannot be found in the Japanese term for "impairment loss". ${ }^{37}$ The Korean translation of IAS 36 (as used by the Korean

${ }^{34}$ The translation into English results from correspondence with Piotr Zegarlinski of PwC (14.7.2016).

35 The translation into English results from correspondence with Satenik Vanyan of PwC (14.7.2016).

${ }^{36}$ We are grateful to Na Zhao for assistance with the translation of the Chinese characters. The third character also has other connotations, but we are informed that "damage" is the most obvious one.

${ }^{37}$ In the Chinese for "impairment loss", 损 is a simplified Chinese character, and it implies damage. The corresponding traditional Chinese character is 損, and this is used in the Japanese 
Accounting Standards Board (KASB) under licence from the IASB) is the only ${ }^{38}$ one of our 19 translations which is 'proximate' and preserves the meaning of damage in its signifier for impairment. ${ }^{39} \mathrm{KASB}$ is a well-resourced standard-setter ${ }^{40}$ which pays particular attention to translation. It reports that:

... due to concerns over possible misinterpretations of IFRS in the process of translations, Korea adhered to the principle of word-for-word translation ... (KASB, 2016, p. 111)

Most of the other signifiers convey (at least in the everyday registers used by readers of annual reports) something much wider than impairment, such as a real loss of value or an accounting write-down. First, much real loss in value is not recognised in accounting; such as when a cost-based non-current asset falls in market value but is still worth more than cost, or when such an asset suffers a temporary fall in market value even if this takes the asset below cost. Secondly, much recognised loss of value of tangible and intangible assets is not "impairment", being caused instead by wearing out or by the passing of time. For assets held at fair value (which can include tangible, intangible or financial assets), ${ }^{41}$ even much of any market-driven recognised loss of value is not

for "impairment". However, in Japanese, our advice (and Google Translate) does not suggest that it implies damage.

${ }^{38}$ One could add the Chinese if one counts the signifier for impairment loss.

39 We are grateful for help from Chungwoo Suh (of the IASB) and Sang-Eun Park (of Samil PricewaterhouseCoopers), who stress that they are offering their personal views rather than official views of their organisations.

${ }^{40}$ For example, KASB has a 'Research Department' of 31 members whereas the German standard-setter has 10 staff (http://eng.kasb.or.kr/fe/org/NR_view.do?deptCd=DEPT00019\&highDeptCd=DEPT00036 and https://www.drsc.de/en/governing-bodies-standing-committees; both accessed on 7.6.2018).

41 The fair value basis is allowed or required for various assets under IAS 2 (para. 3), IAS 16 (para.s 24, 29), IAS 19 (para. 57), IAS 26 (para.32), IAS 27 (para. 10), IAS 28 (para. 11), IAS 
"impairment". To take the example of an available-for-sale financial asset, under IAS 39 (para. 55 (b)), the debits for some falls in value were shown in other comprehensive income but those caused by impairment were shown in profit or loss.

It is not only in the everyday register that confusion might arise from the use of hypernyms in the above translations. Suppose that the IASC had chosen "Loss of Value of Assets" as the title of IAS 36, had defined that phrase as it currently defines impairment loss and had used it thus throughout the standard. Even accountants might then mis-communicate with each other, or need perpetually to ask whether a particular loss of value under discussion was a loss recognised within the rules of IAS 36 or some other recorded or unrecorded loss of value. The translations of "impairment" which use hypernyms bring the possibility of such confusion even among accountants who use the accounting registers of the above languages.

However, the Dutch, Japanese, EU Portuguese and Brazilian Portuguese terms were new in their accounting registers (the first two were coinages, the third a misguided new technical term, and the last a circumlocution), and thus the terms are able to have unambiguously narrow and specific meanings related to IAS 36 , at least to accountants. ${ }^{42}$ In Swedish, the practical problem is minimised by using 'nedskriving' (down-writing) for impairment but 'avskriving' (off-writing) for depreciation. Even for the other languages, we are not suggesting that the above problems have led to erroneous application of IAS

38 (para.s 45, 72), IAS 39 (para.s 9, 43, 47), IAS 40 (para.s 27, 30), IAS 41 (para.s 2, 12, 13), IFRS 6 (para. 12), IFRS 9 (para.s 5.1.1, 5.2.1) and IFRS 10 (para. 31).

42 The authors are grateful for advice about Portugal from Isabel Lourenço of Instituto Universitàrio de Lisboa, and for advice on Japan from Takatsugu Ochi. Google Translate (accessed on 11.12.2016) translates the Japanese characters of Table 1 as 'impairment'. 
36. Accountants and auditors can still properly apply the technical rules of the standard. Furthermore, meanings change over time. For example, although Portuguese accountants were initially bemused by "imparidade", after two decades it has become, even in the everyday dictionaries, an accounting term about loss of value. ${ }^{43}$ In the accounting register in English, the expression "to impair an asset" has perhaps come to mean to write it down according to the rules of IAS 36 . That is, impairment might no longer generally be perceived as the damage or the loss of value but as the action of making the accounting credit entry.

The risk of poor communication caused by hypernyms (as found in most of the translations of "impairment") is even greater under two other circumstances: (i) when investors (those who are not accountants) see the terms in annual reports in these various languages, and (ii) when translators (those who are not as expert as accountants) turn those annual reports into English. Thus, even if IAS 36 is being correctly implemented despite translation problems, there might still be miscommunication at a later stage, as we investigate in the next sections.

In line with our theoretical discussions earlier, we are not suggesting that translators of international standards should always try to approximate the literal meaning of English accounting terms, although that might have worked better for impairment. A counter example is the term "depreciation" in the accounting register in English. This

${ }^{43}$ For example, in Linguee, there are dozens of illustrations of the meaning of the word, all of which are about accounting (http://www.linguee.com/englishportuguese/search?sourceoverride=none \&source=portuguese \&query=imparidade; ; accessed on 11.10.2016). 
might be well understood among accountants but it might confuse readers of annual reports because it signifies loss of value in the everyday register whereas accountants continue to charge depreciation even when an asset rises in value. By contrast, the French "amortissement" or the Italian "ammortamento" are more likely to convey (to translators or investors) the idea that the asset is on its way to the mortuary because of wear or the passage of time. These terms are also better than the German hypernym "Abschreibung" which (if unadorned) can mean either depreciation or impairment.

Thus, the implication for translators of accounting regulations (now most commonly from an English source) is that they should attend to what is being signified. In the case of impairment, although any impairment is measured by reference to a fall in value, the economic event is damage. By contrast, for depreciation, although it is also measured by reference to the eventual expected residual value, the economic event is the passing of time or the gradual wearing out. Translators of regulations should try to maximise the chances that readers in the target language will receive the same message as that received by readers in the source language. In the case of "impairment", more literal translations might have achieved that. But we can go further: with good translation, readers in the target language can sometimes be more likely than readers in the source language to receive the message intended by the writers in the source language. For example, this would be the case when translators from English avoid a literal translation of "depreciation" and focus instead on the process of the asset's dying. 


\section{Annual reports translated into English: prior literature and setting up our investigation}

\subsection{Literature on translated annual reports}

Nearly all the literature about translation and accounting concerns regulations. There has been little examination of the translated annual reports which many firms provide. However, Parker (2000) looks at the popularity of English as a target language for annual reports; Jeanjean, Lesage and Stolowy (2010) explain why certain firms choose to publish such translations; and Jeanjean, Stolowy, Erkens and Yohn (2015) find that there are economic benefits from doing it. None of these papers examines the contents of the translated annual reports, though Mourier (2004) looks at problems met when translating Danish annual reports into English, referring to a few example firms.

Archer and McLeay (1991) studied the translated audit reports provided by 206 European listed firms, revealing the infelicities that result from attempting literal translation. They also conclude that there is some transnational sharing of accounting registers but that it is incomplete. On the issue of TFV, Zeff et al. (1999) explain that Dutch law retains an earlier requirement for financial statements to enable an "inzicht" (insight) into the firm whereas the audit report refers to "een getrouw beeld" (the EU Directive's version of TFV in Dutch). They note (p. 524) that, when Dutch firms provide English translations of the reports, both terms are generally translated as TFV. Campbell, Beck and Shrives (2005) examine the voluntary environmental disclosures provided by German firms. They compare the original German with the translated English disclosures. They comment mainly on issues such as comparative word length and 
whether the two versions cover the same issues, rather than on the quality of the translation of particular words.

Thus, the topic of the quality of translated financial statements and related notes has been the subject of very little research, and the few existing papers use ad hoc examples rather than providing a systematic study of a substantial sample of firms. This is the context for our investigation of the terms used for impairment in corporate annual reports that are translated into English, to which we now turn.

\subsection{Setting up our investigation: sample and data}

We study the notes related to impairment of property, plant and equipment (PPE) in the IFRS reports of listed firms from eleven non-anglophone jurisdictions (hereafter 'countries'): Brazil (BR), Switzerland (CH), China (CN), Germany (DE), Spain (ES), France (FR), Hong Kong (HK), Italy (IT), Japan (JP), South Korea (KR) and Russia (RU). These are home to the largest stock markets in the non-anglophone world that, by 2013, either required IFRS or had many large firms using IFRS. The languages of all these countries were included in our discussion of translations of IAS 36 in Section 3. For nine of the eleven countries, the sample firms comprise the constituents of the major stock market index of the country, and therefore the number of firms per country varies. ${ }^{44}$ China is included by using the IFRS statements of Chinese firms listed both on the Hong

${ }^{44}$ IBrX-50 (Brazil), SMI (Switzerland), DAX-30 \& 10 largest (by market capitalisation) constituents of MDAX-50 (Germany), IBEX-35 (Spain), CAC-40 (France), Hang Seng (Hong Kong), FTSE/MIB-40 (Italy), KOSPI-50 (South Korea) and RTS-50 (Russia). For most countries, the sample comprises the index constituents on 31 December 2005 or 31 December 2010 or both. For Russia and South Korea, the sample comprises the constituents on 31 December 2010. The sample for Brazil comprises the constituents on 30 June 2012. 
Kong Stock Exchange and in Mainland China (so-called 'H Share companies'). ${ }^{45}$ For Japan, we use the reports of those firms which had chosen to use IFRS by 2013. In all cases, we analyse firms using IFRS or versions of IFRS (e.g., EU-endorsed IFRS) which do not differ from IFRS for the issue which we investigate.

Our sample period is 2005 to 2013; that is, we analyse accounting periods ending on 31 December 2005 to those ending on 31 December 2013 or earliest thereafter. If a firm was not listed by 2005 we use the first available annual report; and if a firm was delisted before 2013 we use the last available annual report. For countries which adopted or allowed IFRS later than 2005, our sample period is 2010 to 2013 for Brazil, 2011 to 2013 for South Korea and 2013 only for Japan.

Our initial sample comprises 506 firms. However, so that our country samples are as free as possible from foreign influence, we eliminate foreign firms (e.g. the Belgian Dexia which appeared in the French market index), subsidiaries of listed foreign firms (e.g. Generali Deutschland in Germany because it is a subsidiary of the Italian Generali) and Hong Kong firms with Chinese ultimate parents (e.g. China Mobile). We also exclude subsidiaries of domestic firms that are already included in our sample (e.g. we exclude Gazprom Neft in Russia because it is a subsidiary of Gazprom), so that we have independent observations. Additionally, we exclude firms that use US GAAP in every year, firms where we cannot find English language versions of their annual reports with the required data and firms that do not have a PPE note in any of the sample years. Finally, we exclude firms for which we have less than two years of data, except for

${ }^{45}$ Specifically, our sample comprises the constituents of the Hang Seng China Enterprises Index. 
Japan. The data for all of these filters is hand-collected. These exclusions reduce our sample to 393 firms.

In order to obtain data on the terms used for impairment, we hand-collect from the English language version of the annual reports. We use the first available annual report in our period (mostly, 2005 is available) and from the last (mostly, 2013 is available). For our statistical analyses, we use only a firm's 'first year' and 'last year' but occasionally we refer to other years when discussing the findings. For many firms, we find different terms over time, and we often look at the reports of several years in order to be sure whether or not a particular term is intended to convey impairment. In any report, we begin by looking at the table of movements in PPE. In cases where the table does not make it clear in which line impairment is recorded, we search elsewhere in the following order: the text surrounding the table, the notes on expenses, and the general policy notes on PPE or on impairment. ${ }^{46}$ Particularly where we find broad terms (such as 'write-off' or 'write-down') in the PPE table, we look elsewhere to clarify the meaning. The term 'write-off' is common. It always seems to relate to the disposal or abandonment of assets but, to the extent that some impairment was included, we may have understated the translation problems. In many cases, we also look at the reports in the source languages to assist with this.

${ }^{46}$ In a few cases, we rely on notes about investment property which (when the cost basis is chosen) is accounted for under IFRS as though it were PPE. 


\section{Findings on translated reports}

\subsection{Non-proximate terms for impairment}

In the corporate annual reports translated into target English, we find a great variety of terms for 'impairment'. Some of them are unlikely to mislead the readers of the reports because they are phrases which include the English term 'impairment', such as 'loss in the recovery value (impairment)', 'write-downs for impairment', 'accrual of impairment provision' and 'impairment loss allowances'. Although not misleading, some of these reflect the terms for 'impairment' in the translations of IAS 36, as summarised in Table 1. For example, the first ${ }^{47}$ of the above reflects the Brazilian translation, and the second the Italian. ${ }^{48}$

However, we also found many 'non-proximate' terms, defined as words or phrases which do not include 'impairment' ${ }^{49}$ Examples of why this might matter to the users of financial statements are that: (i) some firms refer to 'depreciation', but a depreciation number has little economic meaning (it is just a pre-scheduled allocation) whereas 'impairment' is supposed to convey surprising bad news, and (ii) some firms refer to 'write-downs' but this could potentially include some or all of depreciation, impairment or abandonment of an asset. In our view, the financial statements containing these non-

47 See Cia. Hering 2010.

48 See Capitalia 2005.

49 There could be several different approaches to scoring. The polar versions are: (i) score 'nonproximate' if there is any such term throughout the report, and (ii) only score if 'impairment' is never used in connection with PPE (which would fail to count non-proximate terms in many reports which contain translation problems). Our approach is intermediate, and our search hierarchy starts in the PPE table, where we expect a reader to look first. 
proximate translations are not 'comparable' with other English-language statements (those of source English and those translated using proximate terms).

Table 2 lists the ten non-proximate terms we found, with their prevalence by country in the 'first year' and 'last year' of firms' reports. Table 3 reports on the overall usage of non-proximate terms for all our countries. As shown in the 'TOTAL' line of Table 3, in the first year, $13 \%$ of firms used non-proximate terms. The last line of the table reports that the international difference in the prevalence of non-proximate terms is highly significant in both years (based on $\chi^{2}$ tests of independence).

Our approach is likely to understate our findings. First, if a firm makes no mention of impairment in a particular year, we do not include it in our statistics, although it might have made impairments and have a hidden translation problem; instead, 'first year' and 'last year' in our statistics include only firm-years in which impairment is mentioned. Second, if a firm mentions impairment in its policy notes but not in its PPE table, it is added to the firms with proximate translations, but a translation problem might have affected its table. Third, if a firm uses an equivalent translation in its PPE table, we do not count non-proximate terms elsewhere in its annual report. Fourth, although we have not systematically analysed this, we found instances (e.g. Italy's Prysmian or Spain's Obrascon Huarte Lain) where the 'first year' does not show a non-proximate term but the 'second year' does (not reported in our tables). Lastly, since we analyse the largest firms in the respective countries, we expect their reports to be the least likely to contain translation problems. 
As Table 3 shows, the non-proximate terms were nearly all confined to four of our eleven countries, so the prevalence in those countries was much higher than the $13 \%$ average, peaking at $39 \%$ for both Germany and Italy in the 'first year'. At first sight, it is particularly surprising that Germany had the joint-highest score because, unusually among our countries, most of its firms had adopted IFRS before 2005 and thus had time to refine their reporting. We return to the issue of country comparisons later.

An important question is: in these annual reports, does the use of non-proximate terms matter? To take the simplest example, we suggest that readers of the English translations of reports provided by French firms are likely to be misled when the reports use 'depreciation' to mean 'impairment'. Also, readers who compare firms internationally might not cope with the variety of terms used for impairment: ten in the case of our sample. When researchers use a database which collects information from annual reports, does this type of problem feed through? In order to provide evidence on this, we look at Worldscope, the key international database for accounting data. It has a data field for impairment of PPE (data code: WC18274). We find cases where Worldscope erroneously records a missing value ('NA') for this field when the translated report used a non-proximate term for impairment. ${ }^{50}$ This suggests that data analysts using Worldscope have been misled by the non-proximate terms.

Can the problem be avoided via eXtensible Business Reporting Language (XBRL)? It cannot because, other than for firms registered with the Securities and

${ }^{50}$ For example, in 2005, Germany's Hannover Rück ('unscheduled depreciation'), Italy's Campari ('write-downs') and Spain's Enagas ('provisions'). 
Exchange Commission in the USA, XBRL is not yet mandatory for external financial reporting of consolidated financial statements. The UK and Ireland are more advanced than most European countries ${ }^{51}$ in the use of XBRL but, even in those countries, XBRL is currently used only for tax filing, which involves applying XBRL tags to numbers in unconsolidated tax-relevant reports which are of little interest to investors.

\subsection{Are the non-proximate terms in annual reports linked to translations of IAS $36 ?$}

We now connect the non-proximate terms found in annual reports (as in Table 2) to the terms used for 'impairment' in the translations of IAS 36 (as in Table 1). As explained in Section 2.2, this does not mean that we are using precise back-translation as a test of the quality of translations. In Section 5.1, we included a number of different terms as conveying proximate information to the single-word 'impairment'.

The non-proximate terms in German reports were: depreciation, unscheduled depreciation, write-downs and unscheduled write-downs. This is clear evidence of a translation problem but not exactly the one we anticipated in Section 3. The terms in the translated reports are, indeed, not proximate to 'impairment'. However, none of them result from translation of the German 'Wertminderung' (as in IAS 36) but from translations of the term in German law (see Appendix 1) that is still being used in German language IFRS reports. As explained in Section 3, in that legal terminology, impairment is a type of off-writing (Abschreibung), in particular an unscheduled one

51 There is as yet no generalised use of XBRL in continental Europe, though this is proposed to begin in 2020 with an initiative termed the European Single Electronic Format (https://www.esma.europa.eu/policy-activities/corporate-disclosure/european-single-electronicformat; accessed 5.6.2018). 
(außerplanmäßige Abschreibung). From before the use of IFRS, 'Abschreibung' has generally been translated into English-language reports as 'depreciation'. This has always been a misleading translation (to the extent that it includes impairment) because impairment is a form of write-down but not a form of depreciation since it is unplanned and unsystematic. So, 'Abschreibung' would be better rendered as 'depreciation and impairment'.

We find no use of 'write-offs' to signify impairment in the translated German reports. Sometimes there is a single heading or line for 'write-downs' which apparently includes both depreciation and impairment, but this reflects the above problem in the source German which commonly uses 'Abschreibung' and is thus misleading because it is too broad to distinguish between the two types of write-down. However, even when a German IFRS report includes the modifying 'außerplanmäßig', the English translation still sometimes merely says 'write-downs' (e.g. BASF 2005 and Bayer 2005 to 2009). In other cases, a firm's PPE table has a single line with an unadorned 'depreciation', such as in Daimler's reports from 2007 to $2013 .^{52}$ We remain confident that there is a translation problem here even if the firm refers to "impairment" elsewhere, as Daimler does for example in the text beneath the PPE table in 2007. That is, we infer that the firm has included impairment in the depreciation line of the table because the firm (or its translator) erroneously considers impairment to be a sub-category of depreciation because of the long-standing and widespread confusion discussed above.

52 Daimler (then DaimlerChrysler) used US GAAP in 2005 and 2006. 
On this type of issue, we might be understating the 'non-proximate' score for some other countries. For example, the PPE table of the Spanish firm Abengoa (2011 report, p. 68) is headed 'Accumulated Depreciation' ('Amortización Acumulada' in the source Spanish table) and the table shows changes in that. However, the text below the table states that "The decrease in the accumulated depreciation is mainly due to the reversal of an impairment", suggesting that the accumulated depreciation includes accumulated impairment. Indeed, the source Spanish report says: "El decrement en el deterioro y amortización acumulada .... la reversión del deterioro”. The English translation of the text is certainly not proximate to the source but (unlike the source) it seems to be a proper reflection of the table's conflated heading rather than necessarily evidencing confusion among the translators. By contrast, Daimler's source reports use 'Abschreibungen' (an appropriate hypernym) which becomes inappropriate only on translation into English. In passing, we note that the conflation of depreciation and impairment found in Spanish and German reports does not comply with IAS 36's disclosure requirements (assuming that the amounts are material), but our topic is not compliance with IFRS.

Interestingly, for some German firms, the translated terms are disconnected from the German source documents. For example, in the case of BASF, the English translations changed from 'write-downs' to 'impairment' for 2006 onwards, whereas the German reports did not change from 'außerplanmäßige Abschreibungen' to 'Wertminderungen' until 2008. Furthermore, for some firms (both German and others), the PPE table is often disconnected from the policy note: the firm uses a term of Table 2 
in its PPE table but 'impairment' in its earlier general policy note. The explanation might be that the policy notes are based on a generic wording provided by the auditors whereas the PPE table is more specific to the firm.

Italy has the joint-highest occurrence of non-proximate terms recorded in Table 2 for the 'first year'. We find: 'write-down', 'value adjustment due to deterioration', 'decrease in fair value' and 'depreciation and write-down'. In the source documents, the 'write-downs' are generally 'svalutazioni' (devaluations). ${ }^{53}$ Thus, the English translations reflect the Italian version of IAS 36 which refers to loss of value (see Table 1), though the mentions of 'deterioration' hint at impairment.

In the Spanish source reports, there is a variety of terms reflecting IAS 36's 'deterioro del valor', such as: 'pérdida de valor', 'pérdidas por deterioro', 'deterioros', and the more general 'provisiones'. As Table 2 shows, in the English translations of the reports this becomes 'loss in value' in one instance but usually 'allowance' or 'provision'.

The French case is the most obvious illustration of our hypothesis that misleading annual reports result from non-proximate translations of IAS 36, because several French firms record 'depreciation' instead of 'impairment'. We can be sure about the problem by looking at the French language reports which say, for example, 'amortissements et dépréciations' in the PPE table, erroneously translated as 'amortization and depreciation'. To take the example of Gaz de France, a heading in the translated table is 'Amortization

53 Such as Parmalat 2013. 
and depreciation' in 2005, then 'Amortization and impairment' in 2006 and 2007, and eventually 'Depreciation and impairment' from 2008. A particularly confusing example is Carrefour 2006, which uses three terms for impairment in a single translated document (its 'Financial Report'): the first table in the PPE note on p. 96 says 'write-down', the table on p. 97 showing changes during the year says 'depreciation', and the PPE policy note on p. 79 says 'loss in value'. This is despite the fact that the firm is aware of the word 'impairment', using it in a policy note on p. 79. This is all the more surprising given that the French version of the report uses "impairment" (which is not a French word) in its PPE tables.

\subsection{Other findings: change over time, language distance and terms for impairment} reversal

The translated reports have generally improved over time. Table 3 shows that the percentage of non-proximate terms falls from $13 \%$ to $5 \%$ from 'first year' to 'last year' (generally from 2005 to 2013). A two-sample test of proportions shows that this improvement is statistically significant at the $1 \%$ level. ${ }^{54}$ Of the four countries discussed above, Germany remains the most conspicuous, and it shows the least improvement over time in relative terms, perhaps because 2005 was not generally the year of first IFRS adoption. The big improvements in France and Spain from first adoption in 2005 suggest 'learning' among firms and auditors, as proposed by Kvaal and Nobes (2012) for IFRS policy choice in those two countries. Using one-sided two-sample tests of proportions, we

\footnotetext{
54 The test uses the 369 observations of all countries except Japan, for which we only have
} observations for 2013. The test is not shown in Table 3; p-value $=0.000$. 
find that the improvements in Spain, Italy, Germany and France are all statistically significant; at the $1 \%, 1 \%, 5 \%$ and $10 \%$ level, respectively. ${ }^{55}$ That the large improvement in France is the least significant can be explained by the fact that it had fewer nonproximate terms in the 'first year' and therefore the power of the test is lower.

A further observation is that, with the exception of Switzerland, the proportion of non-proximate terms bears an inverse relationship to language distance from English. A simple measure of language distance can be based on a classification of languages (e.g. Dow and Karunaratna, 2006, Appendix B). According to this, since English is a Germanic Indo-European language, it is closest to German, of the languages used in the countries of Table 3. Other Indo-European languages are next closest to English and, given the influence of French (and ultimately Latin) on English vocabulary, perhaps the Romance languages (French, Italian, Portuguese and Spanish) are closer than Russian (a Slavic language with a different alphabet). Chinese, Japanese and Korean, since they are not Indo-European languages, are at the greatest distance from English.

Table 3 shows that none of the firms based in the three most distant countries used any non-proximate terms. Two factors help to explain this counter-intuitive result. First, as partly shown in Table 1 and discussed in detail in Section 3, the signifiers used for "impairment" or "impairment loss" in Chinese and Japanese are coinages which translators would tend to seek help with. The second factor is the nature of the translators, who may fall into three types: (i) accountants in the firm, (ii) auditors of the firm, or (iii) translation agencies. Greater language distance may increase the likelihood that the firm

55 The p-values are $0.002,0.006,0.047$ and 0.068 , respectively. 
will seek help with translation. If the reports are translated by international auditors, the reports are more likely to reflect the source English of IAS 36. We have not investigated this issue in detail, but it appears that big-4 audit firms have supervised the translations of Korean reports: the English language version of the consolidated financial statements is often called 'audit report' on the firm's website and the name of the auditor is shown prominently on the front page of some of these. This factor may also explain the lack of problems among Russian firms. Switzerland is a special case because of its longest history of IFRS use and the unusually high use of British accountants in its very large companies ${ }^{56}$ Other researchers might wish to take the topic of this paragraph further.

We finish our report of findings concerning translated IFRS annual reports by referring to the terms used for reversals of impairment. Our data collection followed the same procedures as for impairments. There is plenty of evidence of non-proximate terms for impairment reversal in the annual reports but we do not present tables on this because reversals (or at least disclosures about them) are much rarer than impairments. Again, German and Italian firms provide the most evidence, particularly by using 'write-back'

${ }^{56}$ Camfferman and Zeff (2007, p. 417) explain how Switzerland had set up a standard-setting body in 1984, modelled on Anglo-Saxon precedents. The Federation of Swiss Industrial Holding Companies was the first member of the Board of the IASC to represent companies, starting in 1995. Its delegates were two finance directors from large Swiss companies, one of whom (Malcolm Cheetham) was British (Kirsch, 2006, Appendix III). 
and 'write-up' without reference to impairment or to reversal. ${ }^{57}$ Other potentially misleading terms included 'recoveries' and 'reinstatement of value'. ${ }^{58}$

\section{Conclusions and policy implications}

In an accounting world increasingly dominated by IFRS, translation is of major importance. Nearly all prior study of translations of accounting documents has concentrated on regulations rather than financial statements, and most of it concerns English as the source language. We extend such work by investigating translations of the IFRS term "impairment" into many target languages. However, we then enter a new field: empirical research on the translation of IFRS financial statements into target English. By combining the two aspects of our research, we are able to follow “impairment" from source English, into many translations of IAS 36, and then back into the target English of translated annual reports.

The terms used in accounting documents can create problems in a source language, even before any translation. For example, the accounting register might borrow a term from the everyday register but define it more narrowly (e.g. 'liability') or completely differently (e.g. 'depreciation'). This could mislead non-expert readers of accounting reports.

${ }^{57}$ For example, 'write-back' was used by the German firm RWE (2005 and 2013) and by the Italian firm Banca Popolare di Milano (2005 and 2013); and 'write-up' was used by the German firm Henkel (2005 and 2013) and by the Italian firm Mediaset (2005).

${ }^{58}$ Used, respectively, by the Italian firms Banco Popolare (2013) and Mondadori (2005 and 2013). 
In our study of 19 translations of IAS 36's “impairment", we find that only one (the Korean) uses a signifier which in the everyday register would convey the concept of damage, though another (the Chinese) conveys this in its signifier for impairment loss. The Dutch has a coinage which refers to exceptional loss of value. The Japanese is a coinage referring to decreasing/losing. The EU Portuguese has a term which was new to its accounting register: "imparidade”, which signified something else in the everyday register and seems to have been un faux ami for the translators. The Brazilian Portuguese has a translation of the accounting effect rather than the damage that caused it. In the accounting registers of these languages, the terms can now be understood, by accountants at least, as specifically referring to impairments under IAS 36.

However, there can be no confidence that this is the case for the other 13 translations of 'impairment', which are hypernyms (see the discussion in Section 2). The problem may have been caused because the translators were confused by the somewhat obscure English word and because IAS 36 was remiss in not including a definition of impairment. Instead, the translators focused on the economic result (loss of value) or on the accounting action (writing down). We do not think that the problem was mainly caused by there being no suitable words. For example, the German translators could have used words connected to damage, such as 'Wertschaden' or 'Wertminderungsschaden'. The French translators could have used 'détérioration' or 'dégradation'. ${ }^{59}$ As evidence that the problem is not a lack of proximate terms, arguably the least cognate language to

${ }^{59}$ We are grateful for advice from Jérémy Morales on this issue. 
English, Korean, managed to find a term conveying damage. One possible explanation is that the KASB was trying harder than other translators (see Section 3.2).

The hypernyms are even more likely to be dangerous for readers of annual reports than for accountants. Furthermore, on translation of annual reports into English (which is common), the use of hypernyms or the use of terms which otherwise mean something different in the everyday register is likely to be particularly dangerous. Our empirical research investigated this.

We examined the translated annual reports of 393 firms from 11 countries over the period 2005 to 2013. We found a wide variety of terms for impairment. In firms' first reports in our sample, $13 \%$ of the terms were 'non-proximate' in that they did not include 'impairment' but mostly referred to write-down, depreciation or provision. This leads to errors in international databases which record this information. This problem was not equally spread across countries: nearly all related to Germany (39\% non-proximate), Italy $(39 \%)$, Spain $(27 \%)$ or France $(15 \%)$. By contrast, we found no non-proximate terms in reports from several countries. These include China, Japan and South Korea; and this may be related to the special nature of the three translations, which contain the implication of damage or are coinages. We also suggested that greater language distance from English led to greater reliance on international auditors, who would be familiar with source IAS 36 terminology. Over time, the prevalence of non-proximate terms reduced, though not by as much in Germany and Italy as in Spain and France. The reduction may be due to learning from other firms. We also found non-proximate terms used by firms for reversal of impairment. 
From all this, several policy implications arise. First, the IASB should choose terms which are either coinages or correspond to the use of the terms in the everyday register. In particular, precise concepts should not be given broad terms (hypernyms) which are already in use in the everyday register. In the case of "impairment", the choice of this relatively obscure term with approximately its everyday meaning seems suitable, at least for the English accounting register. However, the failure to define "impairment" in IAS 36 probably contributed to the poor translations. This was not the only occasion on which the international standard-setter has not defined the key term when preparing an accounting standard. ${ }^{60}$ If the IASB were generally to take account of these points, it might help accountants and it would be particularly likely to help the readers of financial statements who are not accountants. This recommendation applies even before considering the need to translate IFRS, but we agree with the Australian and Korean standard setters that the IASB should specifically consider the translation issues of this paragraph when drafting standards (AASB/KASB, 2016, p. 40). Perhaps, following the example of Microsoft (mentioned in Section 2.1), the IASB should create an urtext which is designed to be the source for translations, including into various dialects of English.

We propose that a translator of accounting regulations should strive for 'proximate' translations which convey the source message and do so as unambiguously as possible. We arrive at this conclusion even after assessing skopos theory because, according to the international regulators, the aim of the translation is 'equivalence'.

${ }^{60}$ See Nobes (2012, pp. 90-92) on the lack of definition of "revenue" in the preparatory stages of the development of IFRS 15, Revenue from Contracts with Customers. 
Given that some translations of IFRS are not proximate to the source text, this affects the words selected by preparers of non-English annual reports, as we have shown. This has an important implication for translators of those reports (most commonly into target English): the translators should not necessarily strive for proximate translation of the source reports but should consider the terms in the more distant source IFRS regulation. The firms have deliberately chosen to translate their reports into English but terms such as "loss of value" and "write-down" will not necessarily convey "impairment" to the readers of financial statements in English. More simply, the French term for impairment ("dépréciation") is obviously a trap for translators of reports. Consulting the English terms in source IAS 36 would be useful.

There are also implications for analysts and for researchers. Analysts who read non-English reports prepared under translated IFRS need to be aware that terminology may be misleading. Analysts of reports translated into English should be aware that many different terms for impairment and its reversal are in use. Analysts and researchers should note that the information related to impairment in international databases is likely to contain errors, and we recommend that data should be hand-collected and then carefully checked by experts.

We acknowledge that it was necessary for us to exercise judgement on many matters above. We obtained much expert help, but other researchers might come to different conclusions on some issues. Opportunities for further research include studies of compliance with IFRS disclosure requirements relating to impairment. Prima facie, compliance is lax: impairment is often conflated with depreciation, and impairments are 
often shown net of reversals. It would also be interesting to investigate who translates corporate annual reports (or different parts of the reports) in order to confirm or deny our intuitions on this. 


\section{References}

AASB/KASB (2016) Accounting Judgments on Terms of Likelihood in IFRS: Korea and Australia, AASB Research Report No.2, Australian Accounting Standards Board, Melbourne.

Aisbitt, S. and Nobes, C.W. (2001), "The true and fair view requirement in recent national implementations", Accounting and Business Research, Vol. 31 No. 2, pp. 83-90.

Alexander, D. (1993), “A European true and fair view?”, European Accounting Review, Vol. 2 No. 1, pp. 59-80.

Arden, M. (1993), The True and Fair Requirement Opinion, originally part of the Foreword to Accounting Standards of the Accounting Standards Board; now available at: https://www.frc.org.uk/FRC-Documents/FRC/True-and-FairOpinion,-Arden,-21-April-1993.pdf (accessed 22.12.2016).

Archer, S. and McLeay, S. (1991), "Issues in transnational financial reporting: a linguistic analysis", Journal of Multi-Lingual and Multicultural Development, Vol. 12 No. 5, pp. 347-361.

Baskerville, R. and Evans, L. (2011), The Darkening Glass: Issues for Translation of IFRS. The Institute of Chartered Accountants of Scotland, Edinburgh.

Ballwieser, W. (2001), "Germany - Individual accounts" in D. Ordelheide and KPMG, Transnational Accounting, Palgrave, Basingstoke, pp. 1217-1351.

Camfferman, K., and S.A. Zeff. (2007), Financial Reporting and Global Capital Markets: A History of the International Accounting Standards Committee, 19732000, Oxford University Press, Oxford.

Campbell, D., Beck, A.C. and Shrives, P. (2005), “A note on comparative language interrogation for content analysis: The example of English vs. German", British Accounting Review, Vol. 37 No. 3, pp. 339-350. 
Chau, Simon S.C. (1984), "Hermeneutics and the translator: the ontological dimension of translating", Multilingua, Vol. 3 No. 2, pp. 71-77.

Cooper, D.J. and Robson, K. (2006), “Accounting, professions and regulation: locating the sites of professionalization", Accounting, Organizations and Society, Vol. 31 No. 4-5, pp. 415-444.

Dahlgren, J. and Nilsson, S.-A. (2012), "Can translations achieve comparability? The case of translating IFRSs into Swedish", Accounting in Europe, Vol. 9 No. 1, pp. $39-59$.

Douglas, S.P. and Craig, C.S. (2007), "Collaborative and iterative translation: an alternative approach to back translation”, Journal of International Marketing, Vol. 15 No. 1, pp. 30-43.

Dow, D. and Karunaratna, A. (2006), "Developing a multidimensional instrument to measure psychic distance stimuli”, Journal of International Business Studies, Vol. 37 No. 5, pp. 578-602.

Dunne, K.J. (2006), ‘A Copernican revolution' in K.J. Dunne (ed.), Perspectives on Localization, John Benjamins Publishing, Amsterdam and Philadelphia, pp. 1-11.

Evans, L. (2004), "Language, translation and the problem of international accounting communication", Accounting, Auditing and Accountability Journal, Vol. 17 No. 2, pp. 210-248.

Evans, L., Baskerville, R. and Nara, K. (2015), "Colliding worlds: issues relating to language translation in accounting and some lessons from other disciplines", Abacus, Vol. 51 No. 1, pp. 1-36.

Fuertes-Olivera, P.A. and Nielsen, S. (2011), "The dynamics of terms in accounting. What the construction of the accounting dictionaries reveals about metaphorical terms in culture-bound subject fields", Terminology, Vol. 17 No. 1, pp. 157-180.

Heidegger, M. (1957), Der Satz vom Grund, Neske, Pfullingen. 
Hoffmann, S. and Detzen, D. (2013), "The regulation of asset valuation in Germany", Accounting History, Vol. 18 No. 3, pp. 367-389.

Huerta, E., Petrides, Y. and Braun, G.P. (2013), "Translation of IFRS: language as a barrier to comparability", Research in Accounting Regulation, Vol. 25 No. 1, pp. $1-12$.

IFRS Foundation (2013), Translation, Adoption \& Copyright Policy, IFRS Foundation, London.

IFRS Foundation (2016), IFRS Translation Policy. IFRS Foundation, London. Available at: http://www.ifrs.org/Use-around-the-world/IFRS-translations/Pages/IFRStranslations.aspx (accessed on 7.7.2016).

Jeanjean, T., Lesage, C. and Stolowy, H. (2010), "Why do you speak English (in your annual report)?”, International Journal of Accounting, Vol. 45 No. 2, pp. 200-223.

Jeanjean, T., Stolowy, H., Erkens, M.H.R. \& Yohn, T.L. (2015), “International evidence on the impact of adopting English as an external reporting language", Journal of International Business Studies, Vol. 46 No. 2, pp. 180-205.

KASB (2016), IFRS Adoption in Korea - 5 Years' Experience and Lessons, Korean Accounting Standards Board, Seoul.

Kettunen, J. (2017), "Interlingual translation of the International Financial Reporting Standards as institutional work", Accounting, Organizations and Society, Vol. 56, pp. 38-54.

Kirsch, R.J. (2006), The International Accounting Standards Committee: A Political History, Wolters Kluwer, Kingston-upon-Thames.

Kosmala, K. (2005), “True and fair view or rzetelny i jasny obraz? A survey of Polish practitioners", European Accounting Review, Vol. 14 No. 3, pp. 579-602.

Kosmala-MacLullich, K. (2003), "The true and fair view construct in the context of the Polish transition economy: some local insights", European Accounting Review, Vol. 12 No. 3, pp. 565-587. 
Kvaal, E. and Nobes, C.W. (2012), "IFRS policy changes and the continuation of national patterns of IFRS practice”, European Accounting Review, Vol. 21 No. 2, pp. 343-371.

Moore, M. (2008), The True and Fair Requirement Revisited, Financial Reporting Council, London.

Mourier, L. (2004), "Communicating financial reporting across continents", Hermes Journal of Linguistics, Vol. 32, pp. 145-165.

Nobes, C.W. (1993), "The true and fair view requirement: impact on and of the fourth Directive", Accounting and Business Research, Vol. 24 No. 93, pp. 35-48.

Nobes, C.W. (2006), "The survival of international differences under IFRS: towards a research agenda", Accounting and Business Research, Vol. 36 No. 3, pp. 233-245.

Nobes, C.W. (2012), "On the definitions of income and revenue in IFRS”, Accounting in Europe, Vol. 9 No. 1, pp. 85-94.

Nobes, C.W. and Parker, R.H. (2010), Comparative International Accounting. $11^{\text {th }}$ edition, Pearson, Harlow.

Ordelheide, D. (1990), 'Soft-transformations of accounting rules of the 4th Directive in Germany', Les Cahiers Internationaux de la Comptabilité, Editions Comptables Malesherbes, No. 3, pp. 1-15.

Parker, R.H. (1994), "Finding English words to talk about accounting concepts", Accounting, Auditing \& Accountability Journal, Vol. 7 No. 2, pp. 70-85.

Parker, R.H. (2000), “English and other languages of account”, English Today, Vol. 16 No. 2, pp. 43-56.

Power, M. (2010), "Fair value accounting, financial economics and the transformation of reliability", Accounting and Business Research, Vol. 40 No. 3, pp. 197-210.

Pym, A. (2014), Exploring Translation Theories, Routledge, London. 
Quine, W.V.O. (1969), "Linguistics and philosophy”, in S. Hook (ed.), Language and Philosophy: A Symposium, New York University Press, New York, pp. 95-98.

Rutherford, B.A. (1983), "Spoilt beauty: the true and fair view doctrine in translation", British Accounting Review (then called AUTA Review), Vol. 15 No. 1, pp. 33-36.

Rutherford, B.A. (1985), “The true and fair view doctrine: a search for explication", Journal of Business Finance and Accounting, Vol. 12 No. 4, pp. 484-494.

Saussure, F. de. (1910), Troisième Cours de Linguistique Générale (1910-1911). As edited and translated by E. Komatsu and R. Harris as Saussure's Third Course of Lectures on General Linguistics. Pergamon, London, 1993.

Schäffner, C. (2001), “Skopos Theory”, in M. Baker (ed.), Routledge Encyclopedia of Translation Studies, Routledge, London, pp. 235-238.

Vermeer, H.J. (2012), “Skopos and commission in translation theory” in L. Venuti (ed.), The Translation Studies Reader, third edition, Routledge, London and New York, pp. 191-202.

Walton, P. (1991), The True and Fair View: A Shifting Concept. Occasional Paper No. 7, Association of Chartered Certified Accountants, London.

Zeff, S.A. (2007), "Some obstacles to global financial reporting comparability and convergence at a high level of quality", British Accounting Review, Vol. 39 No. 4, pp. 290-302.

Zeff, S.A., Buijink, W. and Camfferman, K. (1999), "“True and fair' in the Netherlands: inzicht or getrouw beeld?", European Accounting Review, Vol. 8 No. 3, pp. 523548.

Zucca, L.J. and Campbell, D.R. (1992), “A closer look at discretionary writedowns of impaired assets", Accounting Horizons, Vol. 6 No. 3, pp. 30-41. 


\section{Appendix 1}

Terms used for 'impairment' in translations of the title of IAS 36 and in German law (in alphabetical order)

\begin{tabular}{ll}
\hline Language & Term \\
Arabic & 减值 (pinyin: jiănzhí) \\
Chinese & vaerdiforringelse \\
Danish & bijzondere waardevermindering \\
Dutch & arvon alentuminen \\
Finnish & dépréciation \\
French (EU and Canadian) & Wertminderung \\
German & außerplanmäßige Abschreibungen \\
German law & riduzione di valore \\
Italian & 減損 \\
Japanese & 손상 \\
Korean & verdifall \\
Norwegian & utrata wartości \\
Polish & redução ao valor recuperável \\
Portuguese (Brazilian) & imparidade \\
Portuguese (EU) & oбecueneHue \\
Russian & deterioro del valor \\
Spanish (EU and Argentinian) & nedskrivning \\
Swedish &
\end{tabular}

Notes: Apart from the 'German law' line, the terms are those in the title of IAS 36 in official translations. Most of the translations of IAS 36 are those approved by the IFRS Foundation. For many European countries, these are also the official EU versions as attached to EU Regulation 1606/2002. In a few cases (e.g. Italian and Swedish), there is no IFRS Foundation version, so we use the EU version. For the 'German law' line, we translate Handelsgesetzbuch $\S 253(3)$. For the Canadian French, see http://www.nifccanada.ca/normes-internationales-dinformationfinanciere/ressources/normes-ifrs-proprement-dites/item45642.pdf (accessed 7.11.2016). For the Argentinian Spanish, see http://www.facpce.org.ar:8080/miniportal/archivos/2012/NIC/NIC\%2036.pdf (accessed 7.11.2016). 
Table 1.

Literal meanings of terms for 'impairment' in translations of the title of IAS 36 and in German law

\begin{tabular}{ll}
\hline Impairment/damage & Korean \\
Decreasing-losing & Japanese \\
Fall in value & Chinese, Danish, Finnish, French (EU and \\
& $\begin{array}{l}\text { Canadian), German, Italian, Norwegian, Polish, } \\
\text { Russian, Spanish (EU and Argentinian) }\end{array}$ \\
Exceptional fall in value & Dutch \\
Reduction in recoverable value & Portuguese (Brazilian) \\
Reduction in recorded amount & Arabic \\
Writing-down & Swedish \\
Unscheduled off-writing & German law \\
Imparity & Portuguese (EU) \\
\hline
\end{tabular}

Note: These are the authors' own literal translations of the terms in Appendix 1, as assisted by the colleagues noted throughout this paper. 
Table 2.

List of non-proximate terms for impairment found in annual reports translated into English in the first/last year

\begin{tabular}{|c|c|c|c|c|c|c|}
\hline & $\mathbf{B R}$ & DE & ES & FR & HK & IT \\
\hline allowance & & & $3 / 0$ & & & \\
\hline decrease in fair value & & & & & & $1 / 0$ \\
\hline depreciation & & $5 / 4$ & $1 / 0$ & $5 / 1$ & & \\
\hline depreciation and write-down & & & & & & $1 / 1$ \\
\hline loss in value & & & $1 / 0$ & & & \\
\hline provision & $0 / 1$ & & $5 / 1$ & $1 / 1$ & $1 / 1$ & \\
\hline unscheduled depreciation & & $4 / 2$ & & & & \\
\hline unscheduled write-down & & $0 / 2$ & & & & \\
\hline value adjustment due to deterioration & & & & & & $2 / 0$ \\
\hline write-down & & $7 / 1$ & & & & $12 / 5$ \\
\hline
\end{tabular}

Notes: We define 'non-proximate' terms as words or phrases which do not include 'impairment'. The countries are Brazil (BR), Germany (DE), Spain (ES), France (FR), Hong Kong (HK) and Italy (IT).The first number for any country relates to our 'first year' and the second to our 'last year' (mostly 2005 and 2013, respectively). The line for 'unscheduled depreciation' includes instances of 'non-scheduled depreciation' and 'nonregular depreciation'; 'unscheduled write-down' includes 'non-scheduled write-down'; 'depreciation' includes 'net depreciation'; and 'write-down' includes 'write down' and 'writedown'. We report singulars (e.g. allowance) in the table even though many firms use plurals (e.g. allowances); in particular, the plural is used in all but one of the instances of 'write-down'. 
Table 3.

Frequency of non-proximate terms for impairment found in annual reports translated into English

\begin{tabular}{|c|c|c|c|c|c|c|}
\hline \multirow[b]{2}{*}{ Country } & \multicolumn{3}{|c|}{ First Year } & \multicolumn{3}{|c|}{ Last Year } \\
\hline & Firms & \# Terms & in $\%$ & Firms & \# Terms & in \% \\
\hline BR & 36 & 0 & $0 \%$ & 36 & 1 & $3 \%$ \\
\hline $\mathrm{CH}$ & 20 & 0 & $0 \%$ & 20 & 0 & $0 \%$ \\
\hline $\mathrm{CN}$ & 55 & 0 & $0 \%$ & 55 & 0 & $0 \%$ \\
\hline DE & 41 & 16 & $39 \%$ & 41 & 9 & $22 \%$ \\
\hline ES & 37 & 10 & $27 \%$ & 37 & 1 & $3 \%$ \\
\hline FR & 40 & 6 & $15 \%$ & 40 & 2 & $5 \%$ \\
\hline HK & 23 & 1 & $4 \%$ & 23 & 1 & $4 \%$ \\
\hline IT & 41 & 16 & $39 \%$ & 41 & 6 & $15 \%$ \\
\hline JP & - & - & - & 24 & 0 & $0 \%$ \\
\hline KR & 43 & 0 & $0 \%$ & 43 & 0 & $0 \%$ \\
\hline RU & 33 & 0 & $0 \%$ & 33 & 0 & $0 \%$ \\
\hline TOTAL & 369 & 49 & $13 \%$ & 393 & 20 & $5 \%$ \\
\hline$\chi^{2}$ & & & 83.60 & & & 42.11 \\
\hline p-value & & & 0.000 & & & 0.000 \\
\hline
\end{tabular}

Notes: We define 'non-proximate' terms as words or phrases which do not include 'impairment'. The countries are Brazil (BR), Switzerland (CH), China (CN), Germany (DE), Spain (ES), France (FR), Hong Kong (HK), Italy (IT), Japan (JP), South Korea (KR) and Russia (RU). ' $\chi^{2}$ ' and ' $p$-value' report the $\chi^{2}$ test statistic and the corresponding $\mathrm{p}$-value for $\chi^{2}$ tests of independence, respectively. For Japan, only 'Last Year' data are reported because we only use 2013 data for that country. 